\title{
Book Review: Knowledge in the Age of Digital Capitalism: An Introduction to Cognitive Materialism by Mariano Zukerfeld
}

\author{
Rainer E. Zimmermann \\ University of Applied Sciences (HTW), Berlin, Germany, zimmermr@htw-berlin.de
}

\begin{abstract}
Rainer E. Zimmermann reviews Mariano Zukerfeld's Knowledge in the Age of Digital Capitalism. An Introduction to Cognitive Materialism. There are several aspects of innovative thoughts in this text as to recent developments, in particular concerning the manifold occasions of more or less hidden layers of exploitation originating in the use of digital technology, and mainly based on un-remunerated activities. All this speaks very much in favour of reading this book; only minor objections have to be made that should not prevent a profitable reading.
\end{abstract}

It is chiefly the "role of knowledge / and intellectual property within the dynamics of capitalism" (1f.) that is at stake in this interesting work. For the author, "it is not possible to scientifically understand what happens to flows of digital information without understanding how they engage with diverse forms of knowledge [...]" (2) Zukerfeld starts this enterprise from a critique of the ubiquitous tendency to visualise knowledge as something that is an immaterial entity rather than one of the forms of matter proper. This book is essentially based on the author's PhD thesis (Zukerfeld 2010) and concentrates on an updated and developed version of the latter's first volume (3). The book contains six chapters: in the first, the author argues that there are mainly two types of regulations governing the relationship between subjects and goods on the one hand, and capitalism on the other: "[...] those shaped by a physical property and those [shaped] by intellectual property, which in general act simultaneously" (5). He states that "while the former can only be transformed, knowledge can be accumulated" (Ibid.). The important point, then, is that knowledge is visualised "as an emergent property of physical matter" (Ibid.). In the second chapter, the author introduces his somewhat neologistic concept of "cognitive materialism", implying the description of the totality of a variety of knowledge in a given historical situation. This necessitates a typology of forms of knowledge according to its material bearers, of which the author actually gives four: biological, subjective, intersubjective, and objective. (6) Stocks of knowledge are then the topic of Chapter 3, while Chapter 4 discusses the various flows of the types of knowledge. Here, the concept of "translation" is primary, and utilised in order to (re)define the capitalist system itself. As to its underlying structures, Chapter 5 deals with the concepts of regulation, exploitation, and expropriation. The concept of exploitation is described here as something essentially due to asymmetrical exchanges of physical as well as knowledge matter, characterising productive processes such that the exploiter obtains a greater economic value at the expense of the exploited: "Regulation, for its part, consists of the imposition of norms [...] that frame exploitation and expropriation [...while] exploitation means appropriation [...] of surplus value that arises from [...] unremunerated knowledge produced [...]" (7). Zukerfeld here discusses three forms of exploitation: that through alienation, through reproduction, and through attention. The last chapter discusses a theory of social classes for different stages of capitalism, including its mercantile, industrial, and informational forms. 
The immediate merit of the book is that from the beginning on, the author clearly explains those everyday situations that are rarely related to a strict economic framework: for a car, or for a table in a coffee house, the difference between physical and intellectual property is made obvious, a differentiation which is traced back as far as Seneca (12-14). Zukerfeld gives the following definitions: "[...] physical property regulates access to physical matter, which entails what is usually called 'matter' and energy, while intellectual property regulates access to knowledge matter, which encompasses what is commonly labelled as knowledge, information, culture, communication, etc." (15). There is also extensive insight for those who would like to learn something about the possible limits of Marxist approaches: for instance, among other things, one idea is that exploitation might happen without dispossessing means of production (when talking about Internet use, outsourcing, utilisation without contract, or acceptance of advertising). Obviously, these are recent developments that cannot be part of a theory which mainly originates in the 19th century. These are also general questions dealing with access (whether open or not) (80f., 151f.) or licensing (in normative or legal terms) and so forth. Clarification is particularly enhanced by means of the inclusion of a large number of felicitous diagrams (see e.g. tables 3.3 and 5.2 on pages 81 and 159, respectively). As to political action, there is one especially interesting conclusion to the text that puts forward the idea to turn around the famous Feuerbach thesis 11 , namely not to succumb to the temptation to act, but instead to question the "hegemonic ideological coordinates" in the first place. ${ }^{1}$ This not only recalls the ancient Stoic tradition of "asygkatathetein" (non-concurrence) (Hossenfelder 1985), but also recent developments in Critical Geopolitics (cf. Toal (O Tuathail) et al. 2006).

Hence, all in all, the book is a refreshing, dynamic approach leading back into discussions which have been neglected during the last twenty years, while Marxist factions have diversified themselves with a view to minimal variations in their dogmatic approaches - despite all those texts that accompanied the period of the 1989 "Turning". There are several aspects of innovative thoughts as to recent developments, in particular concerning the manifold occasions of more or less hidden layers of exploitation originating in the use of digital technology, and mainly based on unremunerated activities. All this speaks very much in favour of reading this book. So far so good.

However, there are two reservations to be made which might restrict this judgement: on the one hand, the variants indicated as to activities that do not qualify as work, but are nevertheless subjected to exploitation, even if the means of production are possessed by those exploited, are not completely convincing after all. This is mainly because a shift of the hermeneutic perspective might lead to a redefinition of the concept of work itself, depending on the anthropological approach actually chosen. For example, the works of Louis Althusser give various hints as to such a possibility of transforming the classical Marxist approach into something fitting more adaptively to recent developments not anticipated by the theory's originators. It is not surprising, then, that the Althusserian discussion is thus (as it appears) completely absent from this book. This very discussion has led to a revival in Germany, assisted by the recent translation of "Reading Capital" (Althusser et al. 2015). And it may be helpful in finding some more instruments that serve the re-shaping of a sound theory of value which cannot be quite located in this book. (183) The point is that once work is redefined

${ }^{1}$ Zukerfeld quotes Žižek (2002) here (191) from "A Plea for Leninist Intolerance" - one of the rare cases when this can be done in a helpful way. 
(including the affective components alluded to by the author), it may be that the remuneration issue has to be reconsidered also. In this case, the possession of means of production is relevant again in the classical sense. Another ongoing debate might be instructive here, namely that referring to the more optimistic work of Paul Mason (2015). Unfortunately, the latter's book and the subsequent answer provided by Rainer Fischbach (2017) even more recently have been published far too late for the thesis underlying the book discussed here, though for the rewritten version they might have been available.

Secondly, the author remains somewhat vague when introducing the scientific categories, especially with respect to the concept of matter: The historical survey is a little too generous with the space of free play allowed for by the given formulations. It is thus not helpful to the author's issue to talk of "'matter', 'energy' and 'information' (or knowledge matter)" (17), because this is a colloquial usage or rather abusage of language. The line from Aristotle to Einstein (16-21) is equally generous as to the structural details (which are more important than all possible details would be). Altogether it appears that the concept of information is not clearly demarcated from that of knowledge. ${ }^{2}$ A further clarification here could also clarify the author's argument in favour of a joint gnoseological treatment of what he calls the human and the nonhuman (23). This would also shift the perspective more towards physical entities within the world rather than stressing an inherently anthropomorphic perspective as it is probably the case several times in this present book (as in many others on a similar topic).

Nevertheless, with a view to the aforementioned advantages of the book these are only minor objections that should not prevent a profitable reading.

\section{References}

Althusser, Louis, Etienne Balibar, Roger Establet, Pierre Macherey, Jacques Rancière and Frieder Otto Wolf, ed. 2015. Reading Capital [in German]. Münster: Westfälisches Dampfboot. Paris: Maspéro, 1965 sqq.

Fischbach, Rainer. 2017. Die schöne Utopie. Köln: Papyrossa.

Hossenfelder, Malte. 1985. Introduction of Sextus Empiricus: Outline of Pyrrhonic Scepsis [in German]. Frankfurt a.M: Suhrkamp.

Mason, Paul. 2015. Postcapitalism. A Guide to Our Future. Allen Lane: London.

Toal, Gerard (Gearóid Ó Tuathail), Simon Dalby and Paul Routledge, eds. 2006. The Geopolitics Reader [2nd ed]. London: Routledge.

Zimmermann, Rainer E. 2015. Metaphysics of Emergence. Part 1: On the Foundations of Systems. Berlin: xenomoi.

Zimmermann, Rainer E. and José M. Díaz Nafría. 2012. Emergence and Evolution of Meaning. Part 1. Information 2012, 3 (3): 472-503, doi:10.3390/info3030472.

Zukerfeld, Mariano. 2010. Capitalismo y Conocimiento. Materialismo Cognitivo, Propiedad Intelectual y Capitalismo Informacional. 3 vols. Argentina: Facultad Latinoamericana de Ciencias Sociales.

Žižek, Slavoj. 2002. A Plea for Leninist Intolerance. Critical Inquiry 28 (2): 542-566.

\section{About the Author}

Rainer E. Zimmermann

${ }^{2}$ Here Rainer E. Zimmermann and José M. Díaz Nafría (2012) might be helpful. For more detail see also Rainer E. Zimmermann (2015). 
Prof. Dr. Dr. Rainer E. Zimmermann is Professor at the Department of Computer Science, University of Applied Sciences (HTW), Berlin, Germany. His main research areas are Metaphysics and Philosophy of Nature, including Philosophy of Science (particularly of quantum gravity theories) and Ethical Implications, the relationship between ontological and epistemological consequences of the cognitively perceiving and the linguistic modelling as well as designing of the world, especially in terms of spaces, networks, and (evolutionary) systems. 